Creative commons User License: CC BY-NC-ND

Abstracted by: EBSCOhost, Electronic Journals Service (EJS),

Google Scholar, Directory of Open Access Journals (DOAJ),

Journal Seek, Scientific Commons,

Food and Agricultural Organization (FAO), CABI and Scopus
Journal of Agricultural Extension

Vol. XX (X) XXXXXX, 20XX

ISSN(e): 24086851; ISSN(Print); 1119944X

http://journal.aesonnigeria.org

http://www.ajol.info/index.php/jae

Email: editorinchief@aesonnigeria.org

\title{
Mobile Phone Use for Agribusiness by Farmers in Southwest Nigeria http://dx.doi.org/10.4314/jae.v20i2.13
}

\section{Ogunniyi, Michael Dare}

Department of Communication and Language Arts, Faculty of Arts, University of Ibadan, Ibadan, Nigeria

Mobile: +2348063066702

Email: ogunniyidare.m@gmail.com

\section{Ojebuyi, Babatunde Raphael}

Department of Communication and Language Arts, Faculty of Arts, University of Ibadan, Ibadan, Nigeria

Mobile: +2348032804101

Email: ojebabson@gmail.com

\section{Abstract}

This study investigated how farmers in Southwest Nigeria use mobile phones for agribusiness, the benefits of the use of mobile phones, and the challenges farmers face using the device. Driven by theory of information and communication technology for development, this study adopted survey and focus group discussion (FGD) methods. Stratified, random, purposive and convenience sampling techniques were employed to select the sample. A questionnaire and FGD guide were used to collect data. Findings revealed that, among all the mobile phone features, the mostly used feature by farmers is radio at the rate of $75.9 \%$, while the mostly deployed phone service is voice call (83.4\%). Mobile phone use contribute to increase in farmers' income, reduction in transaction and transportation costs, and increase in farm productivity. However, epileptic electricity supply hinders the effective use of mobile phones for agribusiness. Infrastructural facilities, especially electricity, should be provided in the rural areas to enable farmers use mobile phones effectively for agribusiness activities and ensure sustainable agricultural development.

Keywords: Agribusiness, Farmers in Southwest Nigeria, Information and Communcation Technology, Mobile Phones, Sustainable Agricultural Development

\section{Introduction}

In a general sense, when people talk about and clamour for rural development, it is understandable that they talk about agricultural development, in that almost 80 
Creative commons User License: CC BY-NC-ND

Abstracted by: EBSCOhost, Electronic Journals Service (EJS),

Google Scholar, Directory of Open Access Journals (DOAJ),

Journal Seek, Scientific Commons,

Food and Agricultural Organization (FAO), CABI and Scopus
Journal of Agricultural Extension

Vol. XX (X) XXXXXX, 20XX

ISSN(e): 24086851; ISSN(Print); 1119944X

http://journal.aesonnigeria.org

http://www.ajol.info/index.php/jae

Email: editorinchief@aesonnigeria.org

percent of the rural population of Nigeria is engaged in agriculture and agricultural related activities and almost 80 percent of the nation's population reside and work in the rural areas of the country (National Bureau of Statistics [NBS], 2005). Agribusiness such as the production of rice, cocoa, groundnut, cassava, sorghum, oil palm and cotton, among others, accounted for a large chunk of foreign exchange earnings for Nigeria (Okafor and Malizu, 2013), thereby showing the important role agriculture has played and continues to play in the history and development of Nigeria.

Also, agribusiness include the production of daily needs such as honey, pepper, tomatoes, milk and others which according to Amobi (2010) serve both household and medical purposes. In addition, many agriculture and agribusiness activities include the rearing of domestic animals like goats, rams, picks, cow and even rabbits, which are the major sources of meat supplies both to rural and urban population. In fact, the bones accrued from these animals are further used for industrial purposes (Olowu, 2008).

Other aspects of agribusiness activities include harvesting of farm produce, moving of farm produce (like maize, cassava and others) or farm products (like cow, fishes, tomatoes and the likes) from the farm or rural areas to the market or urban areas for selling, storing and preserving of these produce and products throughout the time of sales and even experts needed for selling some of these products (such as slaughters of cows at abattoirs). Each of these agribusiness activities serve as a good source of livelihood and income for many Nigerian both in the rural and urban areas (Okafor and Malizu, 2013).

In order to turn these vast development opportunities offered by agriculture to a national wealth that impacts positively on the citizens, there is the need for effective coordination of the sector by relevant institutions and individuals. This accounted for the move by the Federal Government of Nigeria to initiate the Agricultural Transformation Agenda (ATA) programme. The ATA programme, which was meant to develop agriculture as a business, was set out to create over 3.5 million jobs in the agricultural sector (Kareem and Akinbile, 2015). The ATA programme had four major 
Creative commons User License: CC BY-NC-ND

Abstracted by: EBSCOhost, Electronic Journals Service (EJS),

Google Scholar, Directory of Open Access Journals (DOAJ),

Journal Seek, Scientific Commons,

Food and Agricultural Organization (FAO), CABI and Scopus
Journal of Agricultural Extension

Vol. XX (X) XXXXXX, 20XX

ISSN(e): 24086851; ISSN(Print); 1119944X

http://journal.aesonnigeria.org

http://www.ajol.info/index.php/jae

Email: editorinchief@aesonnigeria.org

implementation strands: Growth Enhancement Support Scheme (GESS) which was designed to enhance timely, efficient and effective delivery of yield-increasing farm inputs such as fertilizer and seedlings at subsidized rates for farmers; Staple Crops Processing Zones (SCPZs) were aimed at promoting private sector's investments for agribusiness development and establish public-private partnership framework for the sustained development of commodity value chains; Nigerian Incentive-based Risk Sharing for Agricultural Lending (NIRSAL) was designed to reduce the risk factor associated with agricultural financing by banks and enhance the flow of credit to agricultural sector value chain actors; and lastly, Commodity Marketing Corporations (CMC) was aimed at improving the marketing environment for agricultural commodities and assuring sustainable pricing and market development.

Although agricultural development programmes are bedeviled with many constraints like poor funding among others, they have shown resilience in the sustenance of agricultural and rural development, especially at the grass root level (Umeh, Ekumankama, Nwachukwu and Ekwe, 2015). However, despite the efforts of the government to improving agriculture, lack of information has been proven to rank highest among other factors for the lower contributions of agriculture to the overall Nigeria's GDP (Olowu and Oyedokun, 2000; NBS, 2005). No doubt, agriculture as a business, or at least as a means of earning income, involves many interactions, and parties involved most times need to travel distances. Notwithstanding, using mobile phones, all these could be achieved without traveling, thereby saving transportation cost and time as well as reduce risks. Mobile phones can also be deployed to complement or reinforce other information sources that can help farmers in their agribusinesses, improve agricultural productivity and ensure sustainable agricultural development.

The arrival of Information and communication technology (ICT), especially mobile phone, is well timed, considering the recent and severe challenges facing agriculture: rising food prices that have pushed over 40 million people into poverty since 2010, the growing global population which is expected to hit 9 billion by 2050, a heightened demand for food and pressure on already over-stretched resources 
Creative commons User License: CC BY-NC-ND

Abstracted by: EBSCOhost, Electronic Journals Service (EJS),

Google Scholar, Directory of Open Access Journals (DOAJ),

Journal Seek, Scientific Commons,

Food and Agricultural Organization (FAO), CABI and Scopus
Journal of Agricultural Extension

Vol. XX (X) XXXXXX, 20XX

ISSN(e): 24086851; ISSN(Print); 1119944X

http://journal.aesonnigeria.org

http://www.ajol.info/index.php/jae

Email: editorinchief@aesonnigeria.org

and the obvious poor communication facilities especially in the rural areas among others (Food and Agricultural Organisation [FAO], 2009; Oxfam, 2011). Now even in rural areas, mobile phones are growing in number and in sophistication, and in fact, from 1999 to 2010, mobile phone penetration, according to International Telecommunication Union (ITU) (2011), rose from 12 per cent of the global population to nearly 79 per cent.

The mobile phones are multifunctional devices - doing much more than simply to place voice calls nowadays, though, in most parts of the rural areas, voice calls is still king, owing to widespread illiteracy and the fact that the calling price system is believed to give more value for money than other features (Mundi, 2011). Another commonly used feature of the mobile phones is Short Message Service (SMS). The first SMS was sent on 3rd December 1992, and by 2008, over 4 trillion text messages were being sent around the globe (ITU, 2011). Especially in the developing countries, organisations and governments are increasingly using SMS to reach out to rural populations that could not previously be contacted. However, current trend among mobile phones users even in the rural areas is now moving from the basic voice and text message capabilities to other available features such as digital camera, voice recorder, flashlight, radio, music player and Bluetooth (Goyal, 2010). Little wonder Aker (2011) predicts that by 2016, there will be 788 million mobile-only Internet users.

The major benefit of the use of mobile phone is that it is used as a platform for exchanging information through calling, SMS or even the Internet. The use of mobile phones improves access to information and making it less costly to obtain (Overa, 2006). Newly discovered agricultural practices, like soil preparation and planting, irrigation and weeding methods, cultivation, harvesting and storage methods, can be sent through texts messages or voice calls on the mobile phone without travelling to the farmers' locations to deliver face-to-face teachings, unlike the usual method of agricultural extension (Aker, 2008). Substituting phone calls for travel ensures safety and reduces farmers' time, cost and perishability of the farm produce (Muto and Yamano 2009). Mobile phones are the only more "accessible device than other 
Creative commons User License: CC BY-NC-ND

Abstracted by: EBSCOhost, Electronic Journals Service (EJS),

Google Scholar, Directory of Open Access Journals (DOAJ),

Journal Seek, Scientific Commons,

Food and Agricultural Organization (FAO), CABI and Scopus
Journal of Agricultural Extension

Vol. XX (X) XXXXXX, 20XX

ISSN(e): 24086851; ISSN(Print); 1119944X

http://journal.aesonnigeria.org

http://www.ajol.info/index.php/jae

Email: editorinchief@aesonnigeria.org

alternatives in terms of cost, geographic coverage and ease of use" (Aker and Mbiti, 2010:10).

However, the use of mobile phones, especially by rural farmers, has some associated challenges. As opined by Alhassan and Kwakwa (2012), mobile phones can best be used for sustaining agricultural development when accompanied by complementary facilities, especially electricity among others, though rural residents still find some means to charge the battery fairly regularly as much as possible (Burrell, 2010). Other challenges include unavailability of mobile phone accessories (Abraham, 2007) while illiteracy can prevent many rural people from taking advantage of some mobile phone features and services which require being able to read (Ahmed and Laurent, 2009). Poor carrier networks can also pose a challenge owing to the fact that the network service infrastructures (masts) have not been installed in many rural areas (Falola and Adewumi, 2011).

Considerable scholarly attention has been focused on the use of mobile telephony and other forms of ICT devices by farmers and other agricultural agents in the function of market economies especially outside Nigeria (Aker, 2008; Jensen, 2009; Muto and Yamano, 2009). Also, some scholars have devoted attentions to the impact of mobile phones use by farmers on agricultural development (Martin and Abbott, 2011; Alhassan and Kwakwa, 2012; Mehta, 2013). Recently in Nigeria, while some studies focused on the adoption and use of mobile phone by agricultural extension workers (Olowu and Oyedokun, 2000; Idrisa, Ogunbameru and Shehu, 2013) a few scholars have studied the use of mobile phone by farmers and its impacts on agricultural development: Falola and Adewumi (2011) focused on three local governments only in Ondo State while Okafor and Malizu (2013) focused on Nsukka and Omor in Enugu and Anambra States respectively. This current study intends to contribute to the existing conversation in the area of mobile phone use in the agricultural sector in Nigeria by focusing on farmers in the Southwest part of Nigeria.

This study is centered on the theory of information and communication technology for development which proposes that mobile telephony is an asset for agricultural 
Creative commons User License: CC BY-NC-ND

Abstracted by: EBSCOhost, Electronic Journals Service (EJS),

Google Scholar, Directory of Open Access Journals (DOAJ),

Journal Seek, Scientific Commons,

Food and Agricultural Organization (FAO), CABI and Scopus
Journal of Agricultural Extension

Vol. XX (X) XXXXXX, 20XX

ISSN(e): 24086851; ISSN(Print); 1119944X

http://journal.aesonnigeria.org

http://www.ajol.info/index.php/jae

Email: editorinchief@aesonnigeria.org

and rural development by enabling the rural farmers to have increased access to information (Martin and Abbott, 2011). As confirmed by Mojisola (2007), the use of the mobile phone in agribusiness to obtain information for sound decision making, especially in buying, selling and contacting potential customers, is capable of improving agribusiness activities. Thus, even if farmers cannot fully operate the mobile phone or there are no enough facilitating amenities, the use of mobile phones by farmers will have positive impact on their agribusiness. Farmers are only needed to be encouraged to use their mobile phone for their agribusiness activities.

\section{Objectives of the Study}

The main objective of this study is to assess the farmers' adoption and use of mobile phones for agribusiness purposes and development in Southwest. The specific objectives were to:

i. examine the rate at which farmers in Southwest Nigeria adopt and use mobile phones features and services for agribusiness purposes;

ii. determine the benefits that the use of mobile phone by farmers brings to agribusiness development in Southwest Nigeria; and

iii. identify various challenges that farmers might be facing in using mobile phones for agribusiness in Southwest Nigeria.

\section{Methodology}

This study was conducted in three Southwestern states. Survey and focus group discussion (FGD) designs were adopted, using questionnaire and FGD guide as research instruments. The questionnaire, which was divided into sections to elicit information based on the objectives, contained variables of mobile phones features such as radio, voice recorder, camera calendar and others; and mobile phones services like voice call, SMS, flashing, internet browsing and multi-media messages. Variables on benefits of mobile phones included increased income, reduction in transaction cost, and easy procurement of agricultural inputs as well as improved farming productivity among others.

Simple random, stratified, purposive, and convenience sampling techniques were employed. First, simple random sampling technique was used to select three states 
Creative commons User License: CC BY-NC-ND

Abstracted by: EBSCOhost, Electronic Journals Service (EJS),

Google Scholar, Directory of Open Access Journals (DOAJ),

Journal Seek, Scientific Commons,

Food and Agricultural Organization (FAO), CABI and Scopus
Journal of Agricultural Extension

Vol. XX (X) XXXXXX, 20XX

ISSN(e): 24086851; ISSN(Print); 1119944X

http://journal.aesonnigeria.org

http://www.ajol.info/index.php/jae

Email: editorinchief@aesonnigeria.org

- Ogun, Osun and Oyo states - out of six in the Southwestern zone in Nigeria. Thereafter, the local government areas (LGAs) in each state were stratified into urban, semi-urban and rural areas. Simple random technique was eventually used to select three rural LGAs from each selected state and three communities in each three rural LGAs, making a total of 27 rural communities. Purposive and convenience techniques were employed to select 10 farmers in each community to make a total of 270 sample farmers. The urban and semi-urban areas were excluded because this study only focused on the rural areas.

Descriptive statistics used to measure and analyse data included frequency count and percentage. Pearson Correlation Co-efficient was the inferential statistics used to test the correlation between farmers' use of mobile phones and improvements on agribusiness activities.

\section{Results and Discussion}

\section{Socio-demographic Characteristics}

Result on Table 1 shows that in Ogun State, the most active age bracket of farmers is 46 to 60 (35.6\%), while in Osun and Oyo states, farmers between age 61 and 70 years were the most active with $31.1 \%$ and 53.35 respectively. In contrast, according to the result, the second most active age bracket of farmers in Ogun state was age 61 to 70 years (24.4\%) while farmers from age 46 to 60 years were the second most active in Osun (30\%) and Oyo (37.8\%).

Also, the result reveals that in Ogun State, there were more female farmers 49 (54.4\%) than male farmers 41 (45.6\%). However, the majority (67) of the farmers in Osun state were males (74.4\%) while female farmers were $23(25.5 \%)$ and similarly in Oyo State, 64 (71.1\%) of the respondents were males while 26 (28.9\%) were females. 
Creative commons User License: CC BY-NC-ND

Abstracted by: EBSCOhost, Electronic Journals Service (EJS),

Google Scholar, Directory of Open Access Journals (DOAJ),

Journal Seek, Scientific Commons,

Food and Agricultural Organization (FAO), CABI and Scopus
Journal of Agricultural Extension

Vol. XX (X) XXXXXX, 20XX

ISSN(e): 24086851; ISSN(Print); 1119944X

http://journal.aesonnigeria.org

http://www.ajol.info/index.php/jae

Email: editorinchief@aesonnigeria.org

Table 1: Distribution of respondents' socio-demographic characteristics

\begin{tabular}{lllll}
\hline Variable & \multicolumn{2}{c}{ States } \\
& Ogun & Osun & Oyo \\
\hline Age & & & & \\
& Below 30 years & 7.8 & 13.3 & 0.2 \\
& 31-45 years & 23.3 & 20 & 7.8 \\
& 46-60 years & 35.6 & 30 & 37.8 \\
& 61-70 years & 24.4 & 31.1 & 53.3 \\
& Above 70 years & 8.9 & 5.6 & 4.4 \\
Sex & Male & 45.6 & 74.4 & 71.1 \\
\hline
\end{tabular}

Rate of Farmers' Use of Mobile Phones Features and Services for Agribusiness

Figure 1 shows that voice call is the mostly deployed service of the mobile phone for agribusiness activities as claimed by $83.4 \%$ of the sampled farmers. This also correlates with the opinions of the farmers interviewed in the focus group discussion. According to a farmer, "Calling is faster and cost-effective and it allows me to contact the person quickly once and for all and I get the response immediately". The second most used mobile phone service is the SMS with $10.0 \%$. However, other services farmers use are flashing $(4.6 \%)$, internet browsing (1.0\%) and social network service $(1.0 \%)$.

Similarly, the most used mobile phone feature by farmers was radio with $75.9 \%$ while the second most used feature was flash light with $9.1 \%$. Other mobile phone features also used by farmers but in a low percentage included calculator $(7.0 \%)$, calendar $(4.0 \%)$, reminder $(2.0 \%)$, and camera and alarm (1.0\% each). Notably, voice recorder was not used by the farmers at all. 
Creative commons User License: CC BY-NC-ND

Abstracted by: EBSCOhost, Electronic Journals Service (EJS),

Google Scholar, Directory of Open Access Journals (DOAJ),

Journal Seek, Scientific Commons,

Food and Agricultural Organization (FAO), CABI and Scopus
Journal of Agricultural Extension

Vol. XX (X) XXXXXX, 20XX

ISSN(e): 24086851; ISSN(Print); 1119944X

http://journal.aesonnigeria.org

http://www.ajol.info/index.php/jae

Email: editorinchief@aesonnigeria.org

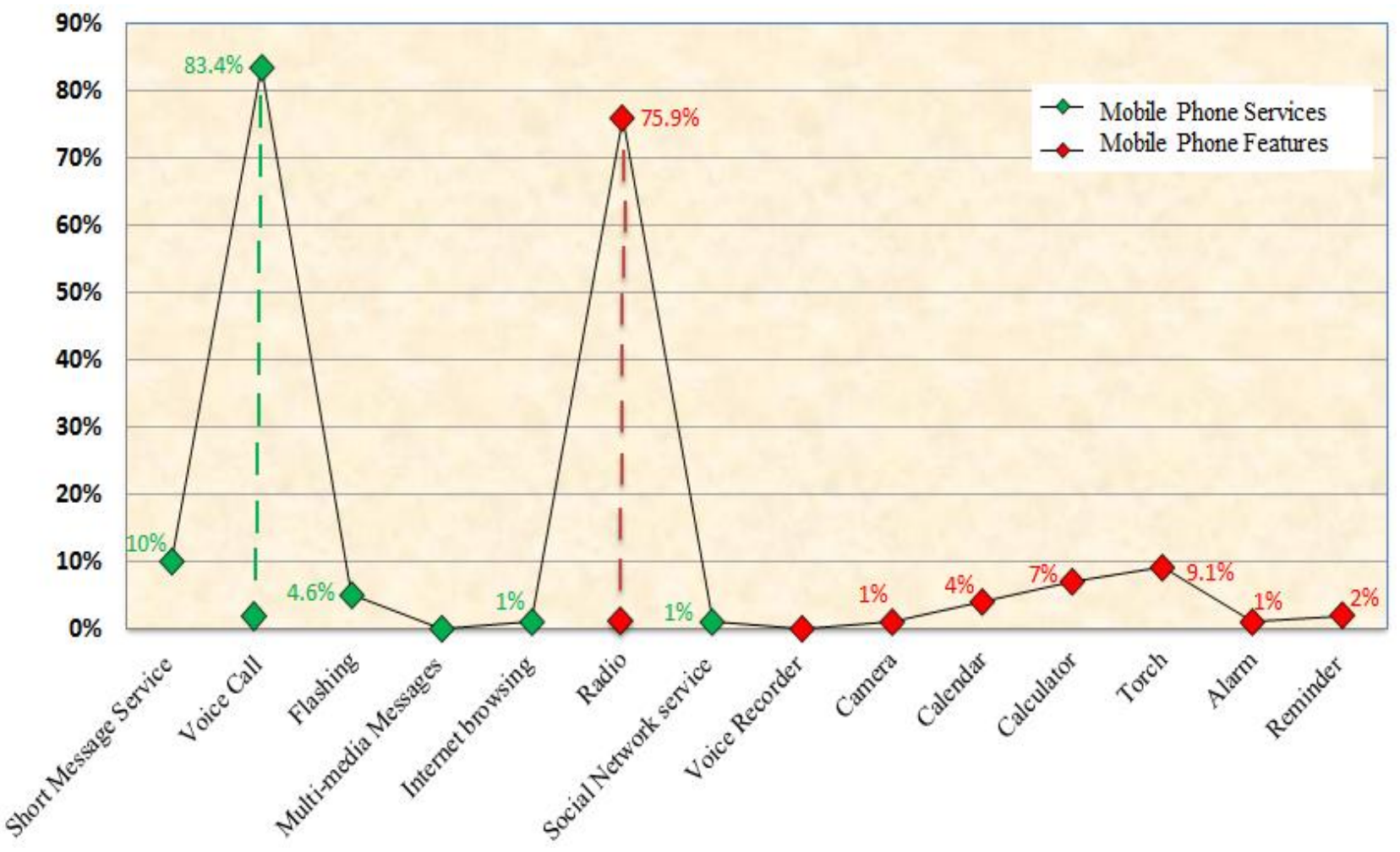

Figure 1: Farmers' Use Mobile Phone Features and Services for Agribusiness Activities

Overall, these findings align with Mundi's (2011) view that though mobile phones are multifunctional devices, voice calls is still king especially in the rural areas. In addition, farmers prefer voice call service to other services of the mobile phones, because voice connectivity is the basic function and it requires only basic literacy (Ahmed and Laurent, 2009).Also the cost effectiveness and timeliness (immediacy) that farmers pointed out as some factors responsible for their use of voice call mostly correlates with Mittal's and Tripathi's (2009) views that by reducing communication costs, the use of mobile phones allows the farmers to gain access to timely quality of information. Unarguably, time saving is important in agribusiness because many crops are extremely time-sensitive, thus farmers who use mobile phones save transport costs, time and reduce the perishability of some farm produce (Muto and Yamano 2009). 
Creative commons User License: CC BY-NC-ND

Abstracted by: EBSCOhost, Electronic Journals Service (EJS),

Google Scholar, Directory of Open Access Journals (DOAJ),

Journal Seek, Scientific Commons,

Food and Agricultural Organization (FAO), CABI and Scopus
Journal of Agricultural Extension

Vol. XX (X) XXXXXX, 20XX

ISSN(e): 24086851; ISSN(Print); 1119944X

http://journal.aesonnigeria.org

http://www.ajol.info/index.php/jae

Email: editorinchief@aesonnigeria.org

\section{Benefits of Farmers' Use of Mobile Phone to Agribusiness}

Findings in Figure 2 reveal that the most prominent benefits farmers derived from the use of mobile phone to agribusiness is increase in farmers' income as claimed by 64 $(23.7 \%)$ farmers. Other notable benefits were reduction in transaction costs and easy procurement of agricultural inputs with $21.1 \%$ and $20.4 \%$ respectively, coupled with an improvement in farming activities (9.6\%). Consequently, $17.0 \%$ agreed that using mobile phones has improved their farm productivity while $8.1 \%$ of the farmers stated that they have been able to acquire new farming techniques using their mobile phones

During FGD, all the discussants were of the opinion that most of the benefits of mobile phone use on their agribusiness are positive so far. According to the consensus view of farmers, most notable benefits include increased income and reduced transportation and transaction costs.

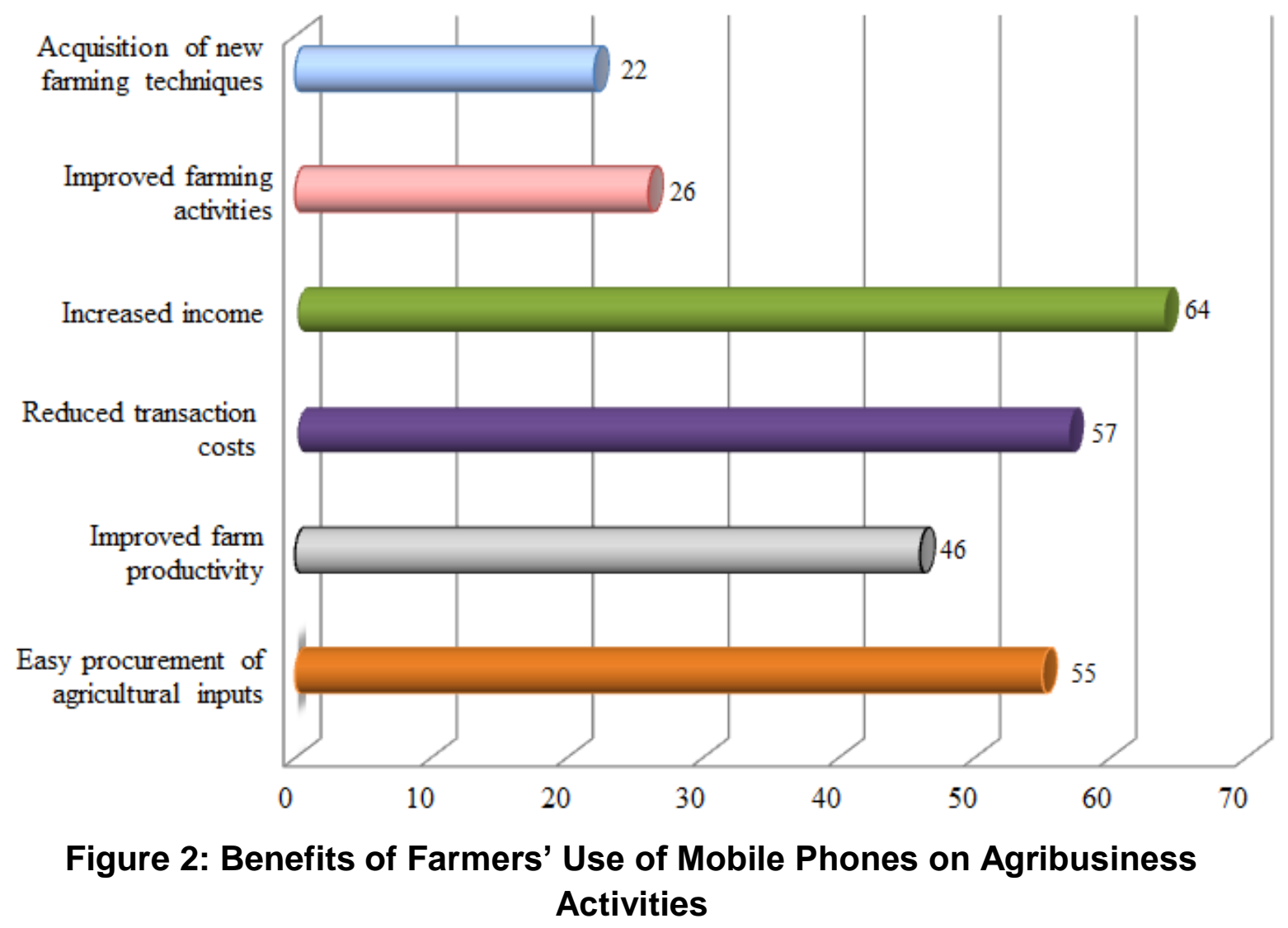


Creative commons User License: CC BY-NC-ND

Abstracted by: EBSCOhost, Electronic Journals Service (EJS),

Google Scholar, Directory of Open Access Journals (DOAJ),

Journal Seek, Scientific Commons,

Food and Agricultural Organization (FAO), CABI and Scopus
Journal of Agricultural Extension

Vol. XX (X) XXXXXX, 20XX

ISSN(e): 24086851; ISSN(Print); 1119944X

http://journal.aesonnigeria.org

http://www.ajol.info/index.php/jae

Email: editorinchief@aesonnigeria.org

In addition to the foregoing, Table 2 shows the relationship between farmers' use of mobile phones and the mode with which they engage their agribusiness activities. The result indicates that the farmers' use of mobile phone has positive influence on the way they go about their agribusiness activities to gain access to market prices and information, contact their potential buyers, purchase farming inputs and enquire new farming practices. The more the farmers use mobile phones, they more they are able to do these activities. However, there is no positive influence of the farmers' use of mobile phone on their loan obtainability. The findings show that farmers have not been able to obtain loans with the use of mobile phones. So, it could be inferred that there is no significant improvement in farmers' ability to obtain loans using the mobile phones.

Table 2: Pearson Correlation Coefficient (PCC) test of relationship between Farmers' Use of Mobile Phones and the level of Benefits on their Agribusiness Activities

\begin{tabular}{lll}
\hline Variables & r-value & p-value \\
\hline $\begin{array}{l}\text { Access to market prices and } \\
\text { information }\end{array}$ & -0.217 & 1.5 \\
\hline Contact potential buyers & -0.216 & 1.4 \\
\hline Purchase of farming inputs & -0.215 & 1.3 \\
\hline Enquire new farming practices & -0.214 & 1.2 \\
\hline Obtain loan & -0.201 & -0.8 \\
\hline * $>0.5$ & &
\end{tabular}

These findings also re-echo the views of Ratnadiwakara, De-Silva and Soysa (2008) that the use of mobile phones have helped farmers to reduce transaction costs in agribusiness from the planting decision to the final selling point of the farm produce. In addition, the overall findings here also conform to the proposition of the theory of ICTD that the use of ICT devices, such as mobile phones, for agricultural activities, has the potential to facilitate rural development, poverty reduction and sustainable agricultural development (Duncombe and Heeks, 2008). The findings here also align with the findings from the studies by Boadi, Boateng, Hinson and Opoku (2007), Ofosu-Asare (2011) and Salia, Nsowah-Nuamah and Steel (2011), that farmers benefitted from mobile phone use by getting better market information through which they were able to make informed decisions, enjoy reduction in transportation cost, have enhanced marketing activities and get increased income. 
Creative commons User License: CC BY-NC-ND

Abstracted by: EBSCOhost, Electronic Journals Service (EJS),

Google Scholar, Directory of Open Access Journals (DOAJ),

Journal Seek, Scientific Commons,

Food and Agricultural Organization (FAO), CABI and Scopus
Journal of Agricultural Extension

Vol. XX (X) XXXXXX, 20XX

ISSN(e): 24086851; ISSN(Print); 1119944X

http://journal.aesonnigeria.org

http://www.ajol.info/index.php/jae

Email: editorinchief@aesonnigeria.org

\title{
Challenges Facing Farmers using Mobile Phones for Agribusiness
}

Figure 3 shows that among the challenges farmers face using the mobile phones for agribusiness, epileptic power supply ranks highest with $29 \%$ followed by poor network signal $(23 \%)$ and unfamiliarity with the phones' features $(16 \%)$. Other challenges are poor internet connectivity (13\%); unavailability of phones' accessories $(11 \%)$ and inaccessibility to recharge voucher $(8 \%)$.

While lamenting on the epileptic electricity supply to their areas, most of the farmers expressed the stress they go through to get their mobile phones charged. One of the farmers lamented that, "when my phone battery is down, I feel uncomfortable, because it will be as if I have missed all the important calls of my customers". Another farmer expressed that, "Because I know electricity supply is general bad, I got a small phone, whose battery usually last long enough for at least three days without charging".

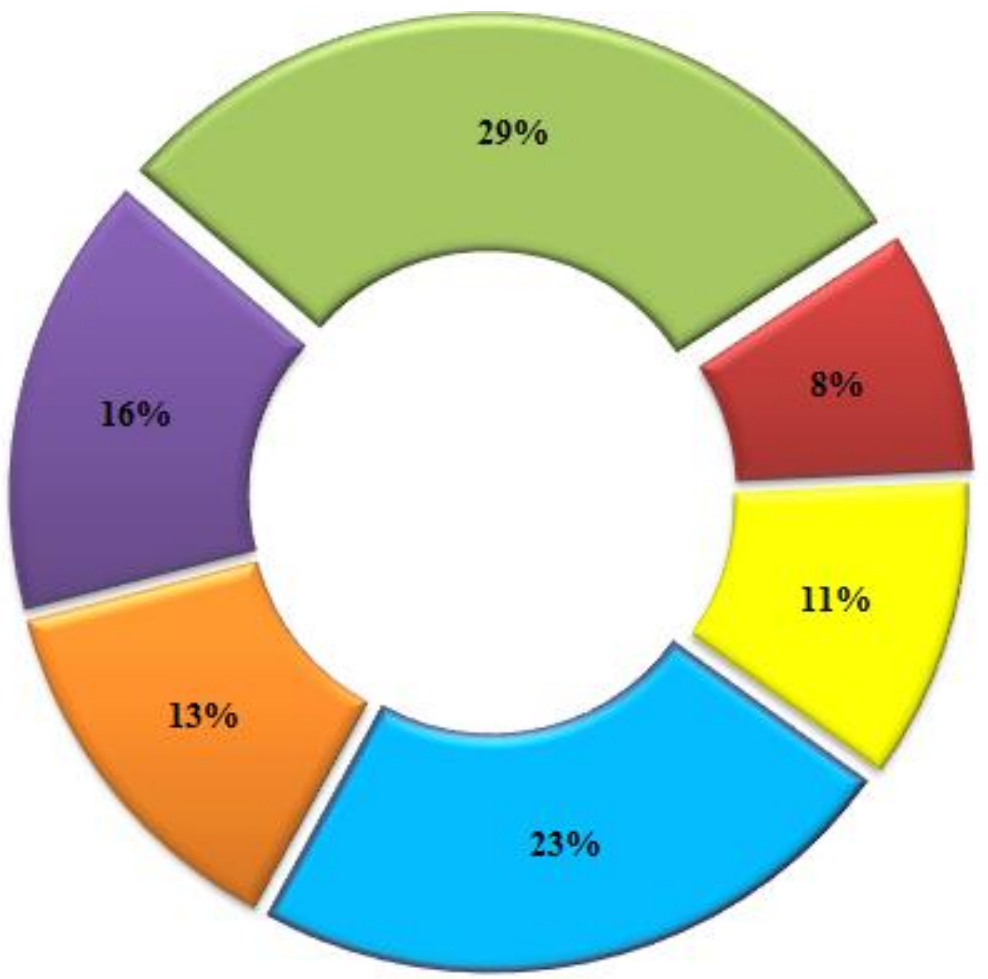

\author{
Poor netw ork \\ signal \\ Moor Internet \\ connectivity \\ Unfamiliarity with \\ phone's features \\ $\square$ Epileptic power \\ supply \\ Inaccessibility to \\ recharge voucher \\ Unavailability of \\ phones' accessories
}

\section{Figure 3: Challenges farmers face while using mobile phones for agribusiness activities}

Findings here reaffirm the concerns raised by Burrell (2010) that effective use of mobile phones depends largely on the availability of electricity. As also opined by Biemans, Swaak, Hettinga and Schuurman (2005), acceptance and use of mobile phones, as any other technological devices, are enhanced where facilitating conditions (such as electricity, good mobile network and internet browsing network, 
Creative commons User License: CC BY-NC-ND

Abstracted by: EBSCOhost, Electronic Journals Service (EJS),

Google Scholar, Directory of Open Access Journals (DOAJ),

Journal Seek, Scientific Commons,

Food and Agricultural Organization (FAO), CABI and Scopus
Journal of Agricultural Extension

Vol. XX (X) XXXXXX, 20XX

ISSN(e): 24086851; ISSN(Print); 1119944X

http://journal.aesonnigeria.org

http://www.ajol.info/index.php/jae

Email: editorinchief@aesonnigeria.org

as the case in this study) are provided. Also, the findings show that illiteracy can prevent many rural people from taking advantage of some mobile phone features and services which require a considerable level of literacy (Ahmed and Laurent, 2009).

\section{Conclusion and Recommendations}

The primary objective of this study was to investigate the current situation in terms of how farmers in southwest Nigeria employed the mobile phones for agribusiness, impact of mobile phone use on farmers' agricultural activities, and challenges that confronted farmers as they used mobile phones to drive their farming business. Overall findings of this study suggest that farmers use the mobile phones, to a large extent for agribusiness activities; and while voice call is the most deployed mobile phone service, radio is the most predominantly usedmobile phone feature by the farmers. Also, the major benefits of the use of mobile phones by farmers include increase in farmers' income, reduction in transaction and transportation costs, and increase in farm productivity. However, epileptic electricity supply, among other challenges, hinders the farmers' effective use of mobile phones for agribusiness.

In spite of the efficacy of mobile phone use for agribusiness, farmers will always be frustrated and eventually underutilize the technology especially when necessary infrastructure and enabling environment are lacking. Therefore, government and other stakeholders should provide adequate infrastructural facilities, especially electricity.

\section{References}

Abraham, R. (2007). Mobile phones and economic development: Evidence from the fishing industry in India Information Technologies and International Development Vol. 4, 1, pp. 5 - 17

Ahmed, T. R. and Laurent, E. (2009). Mobile phones and development: An analysis of IDRC-supported projects Electronic Journal on Information Systems in Developing Countries Vol. 36, 2, pp. 1-16 [Retrieved 27 May, 2015 from http://www.ejisdc.org/ojs2/index.php/ejisdc/article/viewFile/529/265]

Aker, J. C. (2008). Does Digital Divide or Provide? The impact of mobile phones on grain markets in Niger Center for Global Development Working Paper No. 154. [Retrieved $13 \quad$ May, 2015 from http://www.cgdev.org/content/publications/detail/894410]

Aker, J. C. (2011). Dial 'A' for agriculture: A review of information and communication technologies for agricultural extension in developing countries Center for Global Development Working Paper No. 2, pp. 1 - 37 [Retrieved on 20 May, 
Creative commons User License: CC BY-NC-ND

Abstracted by: EBSCOhost, Electronic Journals Service (EJS),

Google Scholar, Directory of Open Access Journals (DOAJ),

Journal Seek, Scientific Commons,

Food and Agricultural Organization (FAO), CABI and Scopus
Journal of Agricultural Extension

Vol. XX (X) XXXXXX, 20XX

ISSN(e): 24086851; ISSN(Print); 1119944X

http://journal.aesonnigeria.org

http://www.ajol.info/index.php/jae

Email: editorinchief@aesonnigeria.org

2015

from

http://www.cgdev.org/files/1425497 file Aker A for Agriculture FINAL.pdf]

Aker, J. C. and Mbiti, I. M. (2010). Mobile phones and economic development in Africa center for global development working paper No. 211, pp. $1-44$ [Retrieved $20 \quad$ May, 2015 from http://www.cgdev.org/files/1424175 file Aker Mobile wp211 FINAL.pdf]

Alhassan, H. and Kwakwa, P. A. (2012) The use of mobile phones by small scale farmers in Northern Ghana: Benefits and challenges Journal of Entrepreneurship and Management Vol. 1, 3, pp. 40 - 45

Amobi, B. O. (2010). Solving unemployment problems through sustainable agricultural production A paper delivered at 34th Annual Conference of Nigeria Statistical Association held in Owerri from 22nd- 24th September, 2010

Biemans, M., Swaak, J., Hettinga, M. and Schuurman, J. G. (2005). Involvement matters: The proper involvement of users and behavioural theories in the design of a medical teleconferencing application Proceeds of GROUP'05, Sanibel Island, Florida, USA

Boadi, R. A., Boateng, R., Hinson, R. and Opoku, R. A. (2007). Preliminary insights into m-commerce adoption in Ghana Information Development Vol. 23, pp. $253-265$

Burrell, J. (2010). Evaluating shared access: Social equality and the circulation of mobile phones in rural Uganda Journal of Computer-Mediated Communication 15:230-50.

Duncombe, R. and Heeks, R. (2002). Enterprise across the digital divide: Information systems and rural micro-enterprise in Botswana Journal of International Development Vol. 14, No. 1, pp. 61-74.

Falola A. and Adewumi, M. O (2011). Constraints to use of mobile telephony for agricultural production in Ondo State, Nigeria Journal of Research in Forestry, Wildlife and Environment. Vol. 4, No. 2, pp. 52 - 63 [Retrieved 12June, 2015 from

http://www.google.com.ng/url?sa=tandrct=jandq=andesrc=sandsource=weban

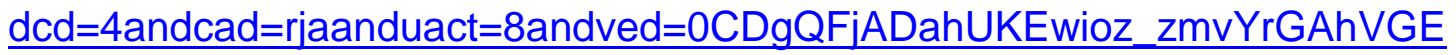
dsKHQZuAOYandurl=http\%3A\%2F\%2Fwww.ajol.info\%2Findex.php\%2Firfwe \%2Farticle\%2Fdownload\%2F84721\%2F74704andei=Vvx6VajMH8ai7AaG3IG wDgandusg=AFQjCNFgVqxigcP ] 
Creative commons User License: CC BY-NC-ND

Abstracted by: EBSCOhost, Electronic Journals Service (EJS),

Google Scholar, Directory of Open Access Journals (DOAJ),

Journal Seek, Scientific Commons,

Food and Agricultural Organization (FAO), CABI and Scopus
Journal of Agricultural Extension

Vol. XX (X) XXXXXX, 20XX

ISSN(e): 24086851; ISSN(Print); 1119944X

http://journal.aesonnigeria.org

http://www.ajol.info/index.php/jae

Email: editorinchief@aesonnigeria.org

Food and Agricultural Organization (2009) 'World Agriculture: Towards 2030/2050" Interim Report

Goyal, A. (2010). Information, direct access to farmers, and rural market performance in Central India. American Economic Journal: Applied Economics Vol. 2, 3, pp. 22-45.

Idrisa, Y. L, Ogunbameru, B. O. and Shehu, H. (2013). Use of information and communication technology (ICT) among extension workers in Borno State, Nigeria In Madukwe, M. C. (ed.) Journal of Agricultural Extension Vol. 17, 1, pp. $70-78$

International Telecommunication Union (2011) ICT Statistics Database [Retrieved on 11th May, 2015 from http://www.itu.int/ict/statistics]

Jensen, R. (2009). The digital provide: Information (Technology), market performance, and welfare in the South Indian Sheries Sector Quarterly Journal of Economics Vol. 122, 3, pp. 879-924

Kareem, H. T. and Akinbile, L. A. (2015) Perceived Contribution of Agricultural Transformation Agenda to Rice Production of Farm Families in Southwestern Nigeria Journal of Agricultural Extension Vol. 19 (2), pp. 34 - 45

Martin, B. L and Abbott, E. (2011). Mobile phones and rural livelihoods: diffusion, uses, and perceived impacts among farmers in rural Uganda Information Technologies and International Development, Vol. 7, pp. 17-34.

Mehta, B. S. (2013). Capabilities, Costs, Networks and Innovations: Impact of mobile phones in rural India Capturing the Gains A Working Paper No. 29, pp. 1 - 32 $\begin{array}{lllll}\text { [Retrieved } & 21 & \text { May, } & \text { 2015, from }\end{array}$ http://r4d.dfid.gov.uk/pdf/outputs/TradePolicy/ctg-wp-2013-29.pdf]

Mittal, S. and Tripathi, G. (2009). Role of mobile phone technology in improving small farm productivity Agricultural Economics Research Review Vol. 22, pp. $451-459$

Mojisola A. A. (2007). Knowledge awareness and attitude of farming communities towards the use of ICTs for rural development: A survey of villages in Kaduna State, Nigeria The Nigerian Journal of Communications Vol. 5, 1, pp. 99

Mundi, I. (2011). Kenya Literacy [Retrieved 23rd May, 2015 from http://www.indexmundi.com/kenya/literacy.html] 
Creative commons User License: CC BY-NC-ND

Abstracted by: EBSCOhost, Electronic Journals Service (EJS),

Google Scholar, Directory of Open Access Journals (DOAJ),

Journal Seek, Scientific Commons,

Food and Agricultural Organization (FAO), CABI and Scopus
Journal of Agricultural Extension

Vol. XX (X) XXXXXX, 20XX

ISSN(e): 24086851; ISSN(Print); 1119944X

http://journal.aesonnigeria.org

http://www.ajol.info/index.php/jae

Email: editorinchief@aesonnigeria.org

Muto, M., and Yamano, T. (2009). The impact of mobile phone coverage expansion on market participation: Panel data evidence from Uganda. World Development Vol. 37, 12, pp. 1887-96

National Bureau of Statistics (2005) Poverty Profile of Nigeria

Ofosu-Asare, K. (2011). Mobile phone revolution in ghana's cocoa industry International Journal of Business and Social Science Vol. 12, 13, pp. 91 - 99

Okafor, G. O. and Malizu, C. F. (2013). New media and sustainable agricultural development in Nigeria New Media and Mass Communication Vol. 20, pp. 66 $-73$

Olowu, T. A. (2008) Assessment of agricultural information needs for CTA's products and services in African Caribbean and Pacific States - Country Study: Nigeria report prepared for the technical centre for agricultural and rural cooperation project

Olowu, T. A. and Oyedokun, O. A. (2000) Farmers' accessibility of agricultural marketing information. Case study of Oyinladun radio programme Journal of Economics in Rural Development. Vol. 14, 1, pp. 109-125

Overa, R. (2006). Networks, distance and trust: Telecommunications development and changing trading practices in Ghana World Development Vol. 34, 7, pp. $301-315$.

Oxfam (2011). "Who Will Feed the World?"

Ratnadiwakara, D., De-Silva, H. and Soysa, S. (2008). Transaction costs in agriculture: from the planting decision to selling at the wholesale market $A$ case-study on the feeder area of the Dambulla Dedicated Economic Centre in Sri Lanka LIRNEasia.

Salia, M., Nsowah-Nuamah, N. N. N. and Steel, W. F. (2011). Effects of mobile phone use on artisanal fishing market efficiency and livelihoods in Ghana The Electronic Journal on Information Systems in Developing Countries Vol. 47, 6, pp. 1 - 26.

Umeh, O. J., Ekumankama, O. O., Nwachukwu, I. and Ekwe, K. C. (2015) Comparative Performance Evaluation of the Agricultural Development Programmes of Abia and Enugu States, Nigeria Journal of Agricultural Extension Vol. 19 (2), pp. $106-114$ 